\title{
Commentary
}

\section{Anti-Black Racism in Canadian Education: A Call to Action to Support the Next Generation}

Emma Stirling Cameron ${ }^{1}, \mathrm{BSc}$, and Keisha Jefferies ${ }^{2}$, MN

${ }^{1}$ School of Health and Human Performance, Dalhousie University

${ }^{2}$ School of Nursing, Dalhousie University

https://doi.org/10.15273/hpj.v1i1.10587

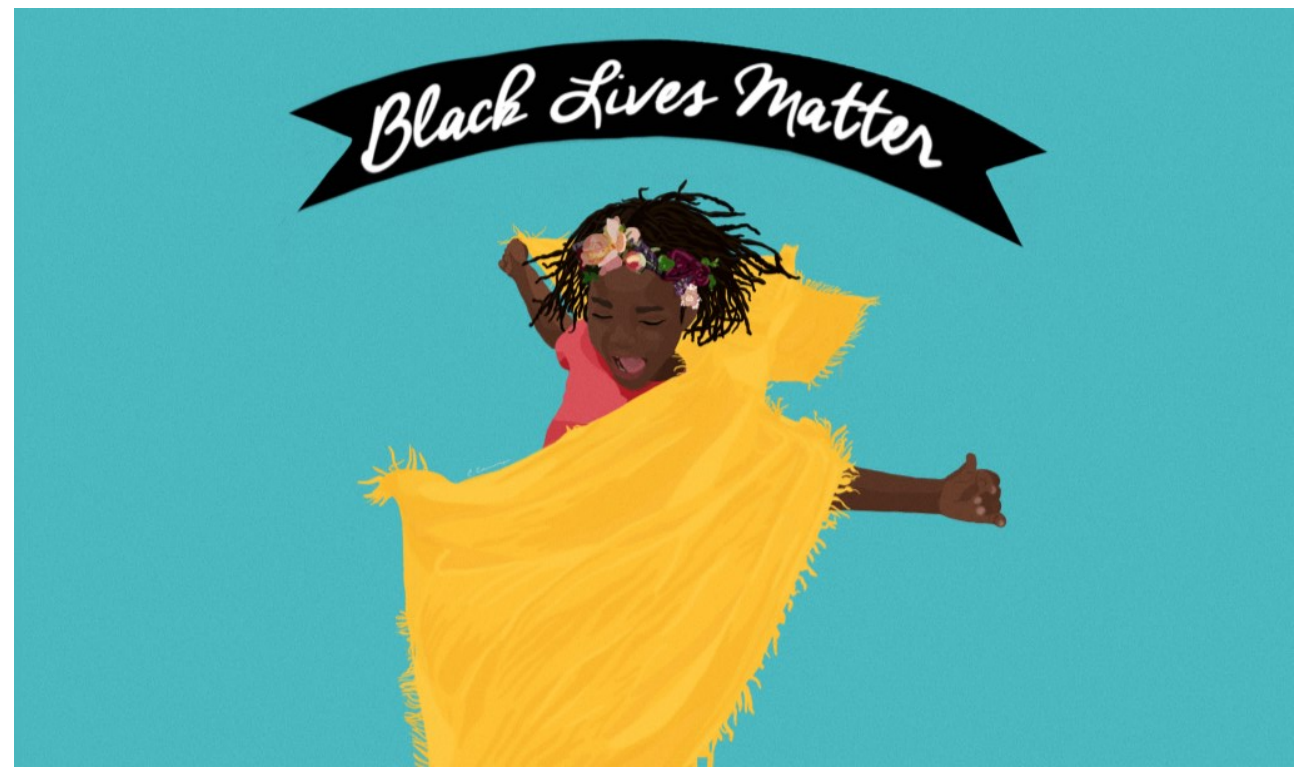

This artwork is dedicated to our daughters, and the next generation of Black learners. For them, we must work diligently to close the achievement gap and improve access to education for Black students and dismantle the legacy of anti-Blackness in public education and the academy, because Black Lives Matter. Artwork by ESC. 
The systematic brutalization of Black people has persisted since colonization, but police murder, global anti-racism protests, and a pandemic that has disproportionately impacted racialized communities have brought anti-Black racism to the attention of the global community. The insidious nature of White supremacy has given birth to anti-Black racism, which has shaped institutions of public and postsecondary education across Canada. Institutional racism is harmful and continues to negatively impact the trajectories of Black lives. For example, Black children are more likely to be enrolled in under-resourced schools, receive harsher punishments, and be streamed into non-academic programming regardless of academic potential and capability. Moreover, Black students are less likely to attend university, despite wishing to, and Black educators remain under-represented and undervalued, despite their immeasurable contributions to academia and the Black community. These examples represent a concerted effort to guard White spaces and keep Black people from accessing equal opportunity through basic access to education. This paper is a call to action for all educators, allies, and institutions to begin to make reparations and end the racial hierarchy and systematic antiBlack oppression across Canada because Black Lives Matter.

Many Black students in Canadian public schools receive an education that is separate and unequal from that of their peers (Teklu, 2012), steeped in a legacy of segregation and antiBlackness-a disparity that has gone largely unchanged for decades (Black Learners Advisory Committee, 1994). With majority White teachers and Eurocentric curriculalargely ignoring Canada's history of enslavement and segregation (Black Learners Advisory Committee, 1994)—students report feeling unwelcome and unseen. Only $54 \%$ of Black students report feeling supported by their teachers (Rankin et al., 2013). Often seen as a threat to the education of their White peers (Maynard, 2017), Black youth-especially Black boys-face more frequent, severe punishments.
Black students accounted for half of all expulsions in Toronto in 2016 (Chadha et al., 2020). Black students are more likely to be pushed into non-academic streams and away from STEM subjects, a phenomenon referred to as second-generation segregation (Maynard, 2017; Mickelson, 2007); From 2006-2011, 53\% of Black students in the Toronto area were in an academic stream, compared to $81 \%$ of White students (Chadha et al., 2020). Black high school students, regardless of their grades, are often dissuaded from university education and pushed toward vocational training (Gaynair, 2017; Maynard, 2017). Consistently undervaluing and criminalizing Black students contributes to psychological stress and harm, impacting child development and disincentivizing students from attending classes and continuing their education (Black Learners Advisory Committee, 1994). Just 69\% of Black students graduated high school in Toronto between 2006 and 2011, compared to 84\% of White students. While almost $60 \%$ of non-Black students applied to post-secondary school, only $42 \%$ of Black youth applied (Chadha et al., 2020).

Universities across Canada remain privileged, predominantly White spaces. Despite $94 \%$ of Black youth in Canada reporting that they would like to obtain a bachelor's degree (or higher), only $60 \%$ reported thinking it was attainable (Statistics Canada, 2020). Students whose dreams of higher education were not thwarted by unsupportive, punitive, public education still face barriers to entering and remaining in undergraduate programs. The exponentially rising cost of tuition across Canada and the continued reliance on meritbased admission disadvantages Black students, who are two times as likely to live in a lowincome household (Statistics Canada, 2020). At Dalhousie University in Nova Scotia, only $2 \%$ of the student body is Black, compared to a $5 \%$ population rate in the province (Bombay \& Hewitt, 2015). Student experiences depict a normalization of anti-Blackness on campusesmicroaggressions, racial slurs, privatized policing, violent threats, and even outspoken disdain from professors-most of which is often 
dismissed by those in positions of power (Bell et al., 2020). Buildings and statues on campus pay homage to slave owners and segregationists (e.g., George Ramsay at Dalhousie University, Halifax; James McGill at McGill University, Montreal); it is a stark reminder of the origins of the academy. Students who have not been pushed out and continue into graduate studies describe encountering covert racism from spaces that preach liberalism: struggling to find supervisors, being discouraged from pursuing critical research, and being held to higher academic standards than White students (Bell et al., 2020).

Black faculty members are underrepresented across Canadian universities. For example, Black faculty at McGill University constitute only $0.8 \%$ of their faculty, despite accounting for $4 \%$ of Quebec's population (Hinkson \& Shingler, 2020). Black professors earn lower salaries than their White colleagues and are less likely to be promoted and awarded tenure, despite a high level of academic achievement (Henry et al., 2017). A Black faculty member in Henry and Tator's (2012) study said, "I was told by a senior racialized colleague that you have to publish 20 times better than your White colleagues to get tenure" (p. 89). Often referred to as Black tax (Gewin, 2020), the few racialized faculty that often exist within a department are repeatedly asked to serve on diversity committees and admission boards, all in addition to their regular demands of teaching and research. This is in addition to supervising higher rates of students (mostly of colour) and partaking in community activism and policy work to better the Black community-all of which typically goes unpaid and unrecognized, and is not considered in tenure applications. Black faculty are, therefore, undercompensated for the amount of scholarship and leadership they actually engage in and have less time to devote to research and publication, which remains a critical marker of academic success and productivity (Gewin, 2020).

We put forward a short list of calls to action for individuals and public and private institutions to enact to better address gaps in educational access, attainment, and achievement for Black learners and educators:

- establish Afrocentric curricula for public and post-secondary institutions (e.g., African Canadian Studies course in Nova Scotia high schools [Province of Nova Scotia, 2015]; Africentric Alternative School [James, 2011]; Black and African Diaspora Studies [McNutt, 2020]);

- implement funding programs to train and employ Black teachers (Black Learners Advisory Committee, 1994);

- survey programs/faculties to determine what has been successful in increasing the representation of Black students and implement strategies to recruit and retain Black students and faculty (e.g., University of Toronto Faculty of Medicine Black Student Application Program recruited 24 Black medical students in 2020, the most in Canadian history; Collie, 2020);

- work to tackle personal biases, while also working to dismantle systemic racism in meaningful, non-performative ways (Bell et al., 2020);

- recognize and compensate Black staff for invisible labour (e.g., panels, committees) and community contributions (Gewin, 2020);

- increase designated undergraduate and graduate scholarships or tuition waivers for Black students (see Mount Saint Vincent University and Memorial University tuition waiver for foster children; Bombay \& Hewitt, 2015; McPhee, 2020); and

- advocate for the improvement of the social and economic conditions that systematically and disproportionately impact Black families, in meaningful, nonperformative ways. This includes the following:

- coverage for quality daycare/child care

- financial investment in historically/predominantly Black communities and schools

- basic income and living wages $(\$ 2,100$ per month in Canada; WageIndicator Foundation, 2020)

$\circ$ free tuition and student debt relief 
Despite a lasting legacy of racial inequities and hierarchies, Black families, educators, and activists have resisted centuries of White oppression and segregation. In 2017, nearly $70 \%$ of Black adults in Canada had a postsecondary diploma of some kind and the majority of the Black population reported that their education and employment opportunities were better than those of their parents (Statistics Canada, 2020). These improvements in income and quality of life are owed to the generations of Black leaders and activists who fought persistently for equity and inclusion (most of whom have pushed for the implementation and awareness of the listed calls to action). It is imperative for the next generation of learners that swift, widesweeping, evidence-based action be taken to improve the accessibility of quality education for Black learners (Black Learners Advisory Committee, 1994; Chadha et al., 2020; Maynard, 2017).

\section{Acknowledgements}

The authors would like to acknowledge that Black learners are not the only population who has experienced systematic oppression. Indigenous learners across Turtle Island have had their own experiences of colonization, assimilation, and discrimination, all of which impacts their access to quality education. Many of these calls to action extend to Indigenous students and faculty.

\section{References}

Bell, M. P., Berry, D., Leopold, J., \& Nkomo, S. (2020). Making Black Lives Matter in academia: A Black feminist call for collective action against anti-blackness in the academy. Gender, Work and Organization, 28(S1), 39-57. https://doi.org/10.1111/gwao.12555

Black Learners Advisory Committee (NS). (1994). BLAC report on education: Redressing inequity - Empowering Black learners. https://www.ednet.ns.ca/docs/blacreport-education-redressing- inequity.pdf

Bombay, A., \& Hewitt, K. (2015). A report from the Committee on Aboriginal and Black/African Canadian Student Access and Retention: A focus on financial support.

https://cdn.dal.ca/content/dam/dalho usie/pdf/dept/senioradministration/VPAP/reports/otherrep orts/Aboriginal\%20and\%20BlackAfrican $\% 20$ Canadian $\% 20$ students $\% 20$ \%20Final\%20report\%200ct\%201\%20 2015.pdf

Chadha, E., Herbert, S., \& Richard, S. (2020). Review of the Peel District School Board. Ontario Ministry of Education. http://www.edu.gov.on.ca/eng/new/re view-peel-district-school-board-reporten.pdf

Collie, M. (2020, June 2). 24 Black medical students accepted to $U$ of $T$ medicine the most in Canadian history. Global News. https://globalnews.ca/news/7010646/ 24-black-medical-students-accepted-uof-t-medicine/

Gaynair, M. H. (2017, May 23). Learning while Black: I was streamed to fail. Huffington Post. https://www.huffingtonpost.ca/mhyacinth-gaynair/learning-whileblack_b_16706474.html?utm_campaign =canada_dau

Gewin, V. (2020). The time tax put on scientists of colour. Nature, 583, 479-481. https://doi.org/10.1038/d41586-02001920-6

Henry, F., Dua, E., Kobayashi, A., James, C., Li, P., Ramos, H., \& Smith, M. S. (2017). Race, racialization and Indigeneity in Canadian universities. Race Ethnicity and Education, 20(3), 300-314. https://doi.org/10.1080/13613324.20 16.1260226

Henry, F., \& Tator, C. (2012). Interviews with 
racialized faculty members in Canadian universities. Canadian Ethnic Studies, 44(2), 75-99.

https://doi.org/10.1353/ces.2012.0003

Hinkson, K., \& Shingler, B. (2020, October 1). McGill promises to hire more Black professors, but the statue of its founder will stay. $C B C$.

https://www.cbc.ca/news/canada/mo ntreal/mcgill-montreal-anti-blackracism-1.5746283

James, R. (2011, November 14). James: Africentric school's legacy of success must graduate to high school. Toronto Star. https://www.thestar.com/news/gta/2 011/11/14/james_africentric_schools_l egacy_of_success_must_graduate_to_hig h_school.html

Livingstone, A. (2011). Black youths' perspectives on education challenges and policy. Academia. https://www.academia.edu/11447204 /BLACK_YOUTHS_PERSPECTIVES_ON_E DUCATION_CHALLENGES_AND_POLICY

Maynard, R. (2017). Policing Black lives: State violence in Canada from slavery to the present. Fernwood.

McNutt, R. (2020, June 12). Commitment and action on anti-Black racism: Work moves forward on new academic and research programs. Dal News. https://www.dal.ca/news/2020/06/12 /commitment-and-action-on-antiblack-racism--work-moves-forwardo.html

McPhee, J. (2020, November 16). MSVU to launch pilot project offering free tuition for foster care students. The Chronicle Herald. https://www.thechronicleherald.ca/ne ws/local/msvu-to-launch-pilot-projectoffering-free-tuition-for-foster-carestudents-521105/

Mickelson, R. A. (2007). First- and second- generation school segregation and the maintenance of educational inequality. In R. Teese, S. Lamb, \& M. Duru-Bellat (Eds.), International Studies in Educational Inequality, Theory and Policy (pp. 357-373). Springer. https://doi.org/10.1007/978-1-40205916-2_13

Province of Nova Scotia. (2015). African Canadian Studies 11: Outcomes. https://curriculum.novascotia.ca/sites/ default/files/documents/outcomesindicators-files/African\%20Canadian\% 20Studies\%2011\%200utcomes\%20\%2 82015\%29.pdf

Rankin, J., Rushowy, K., \& Brown, L. (2013, March 22). Toronto school suspension rates highest for black and aboriginal students. Toronto Star. https://www.thestar.com/news/gta/2 013/03/22/toronto_school_suspension _rates_highest_for_black_and_aboriginal _students.html\#: :text=Toronto school suspension rates highest for black and aboriginal students,-JB\&text=Black students were three times,the Toron

Statistics Canada. (2020, February 25). Canada's Black population: Education, labour and resilience. https://www150.statcan.gc.ca/n1/pub /89-657-x/89-657-x2020002-eng.htm

Teklu, M. (2012). Canada's forgotten children: Written submissions to the Committee on the Rights of the Child on the third and fourth reports of Canada. African Canadian Legal Clinic. https://www2.ohchr.org/english/bodie s/crc/docs/ngos/Canada_African_Cana dian_Legal_Clinic_CRC61.pdf

WageIndicator Foundation. (2020). Canada living wage, individual. Trading Economics. https://tradingeconomics.com/canada/ living-wage-individual\#: : text=In the long-term $\% 2 \mathrm{C}$ the,according to our econometric models. 